\title{
Organizational Knowledge Management Policy as Key Performance Factor
}

\author{
Nasser Fegh-hi Farahmand \\ Department of Management, Tabriz Branch, Islamic Azad University, Tabriz, Iran \\ E-mail: farahmand@iaut.ac.ir
}

Received: April 6, 2018 Accepted: April 17, $2018 \quad$ Published: April 25, 2018

doi:10.5296/csbm.v5i1.13056 URL: http://dx.doi.org/10.5296/csbm.v5i1.13056

\begin{abstract}
This paper proposes a relation of organizational knowledge management policy by benevolent superintendence and reviews the organizational knowledge management planning and performance measurement literature to develop a conceptual model and research propositions. Organizational knowledge management strategy involves adding some new but unrelated products and services to their existing ones and knowledge management policy them to their current customers. This strategy is concerned when a organization tries to increase its control by acquiring organizations that supply it with input or organizations that are customers for its output. It aims at excelling in the competition by offering products with the lowest cost. Data are drawn from a survey of the comfort organizations in comfort organizations that around few samples of benevolent superintendence engage in organizational knowledge management policy. The interview schedule was designed to collect data on a number of benevolent superintendence and strategic characteristics in addition to asking about the presence or absence of an organizational knowledge management policy and, where appropriate, the time period to which the plan applied. Interviews were conducted face to face directly within the workplace, training and consultant sessions or indirectly by e-mail or using structured questionnaire.
\end{abstract}

Keywords: Organizational Knowledge Management, Benevolent Superintendence, Comfort Organizations 


\section{Introduction}

The focuses are on the relationship between organizational knowledge management policy and strategic benevolent superintendence. The benevolent superintendence characteristics showing a significant association with a commitment to organizational knowledge management policy and also organizational knowledge management policy showed a positive association with that benevolent superintendence with a growth orientation. It is concluded that benevolent superintendence characteristics can be important in explaining and compilation the organizational knowledge management policy within the comfort organizations for implementation of organizational knowledge management planning. In fact, comfort organizations influence whether or not those organizations engage in organizational knowledge management planning. In this field, the focus is on the special characteristics of benevolent superintendence such as education type and level. Although development of models appropriate for organizational knowledge management policy is appeared to be of requirement, previous researches in this field have rarely taken it into consideration.

Therefore, in the current study, using an organizational knowledge management policy, but related fields of study have been combined to each other, and a new model in this field was proposed by employing an exploratory methodology. In organizational knowledge management strategy a substantial modification of organization and its products are required, i.e., high organizational knowledge management policy. These modified products are presented to current customers though the existing channels, thus, there is no fundamental need for the investigation of external environment and affairs, and organization should give priority to taking the internal environment into consideration. A substantial body of research studies has been conducted on organizational knowledge management policy and strategy separately. Furthermore, this study provides off the new idea of examining the relationship between organizational knowledge management policy and prioritization of internal or external environments. The knowledge management field is now giving high priority to developing knowledge management metrics.

Homogenous Diversification strategy: diversification strategy implicates an organization's attempts for adding new but related products and services to its existing ones.

Organizational knowledge management policy as key performance factor strategy is concerned with maintenance of the status quo.

The authors also concluded that employee perceived support by top superintendence for organizational knowledge management and innovation is associated with employee perceived service quality and client adherence to their service plan, as mediated by supervisor support for employee empowerment and development, trust in superintendence and affective commitment to the organization.

\section{Knowledge Management Policy}

The employee perceived support by top superintendence for organizational knowledge management and innovation is associated with trust in superintendence and affective commitment to the organization, as mediated by supervisor support for employee 
empowerment and development. The organizational knowledge management is production in massive amount with low prices, which is labeled as economy of scale. Strategic organizational knowledge management policy is a new paradigm in the field of organizational knowledge management policy, which was under focus of the current study with regard to its role in organizations' development. It is believed the innovation and knowledge management policy have a direct effect on organizational presence and the ability of creating a sustainable competitive advantage. benevolent superintendence in comfort organizations are responsible for building organizations where people are continually expanding their capabilities to shape their future-that is, benevolent managers are responsible for organizational knowledge management.

The employees who had trust in their superintendence were performing, cooperating and dedicating their full efforts to the assigned task. The benevolent manager's attitudes towards employee involvement were related to unit manager attitudes and to employee attitudes. The top superintendence supports a work climate in which employees may innovate and learn from one another, supervisors will then feel freer to provide greater latitude for employees to make appropriate decisions as well as grow and develop.

This study is based on a sample of small comfort organizations and the influence of organization characteristics such as organizational knowledge management policy of organization have been well explored over the last decades. The random sample participated in the survey based on face to face, meeting, advising, questionnaire, participation in consultant sessions and e-mail interviews using a semi structured interview schedule. Benevolent managers could answer the key questions about the environmental and strategic variables in which interested and thus the use of a small number of senior managers is not as problematic as it would have been if interested in the psychological and personality characteristics of the benevolent superintendence.

Benevolent superintendence organization related characteristics were also included to check for the presence of any uncontrolled organization variables. Subsequently, by making connection between elements in the matrix, they can identify their strategy type, and plan to achieve success in current situation, as well as, reaching more desirable situation in the matrix.

One of the most stable methods of development is knowledge management policy strategy. By knowledge management policy, products and presenting new or modified products to the market, novel competitive privileges for an organization are created, and if this process continues the organization could easily took the responsibility of the market leadership, and stop being in a passive state.

\section{Knowledge Management Policy}

A brief situational analysis of comfort organizations, which indicate that knowledge management action, is characterized as a practice unless supported by the theory. The reforms to the curricula have been established empirically, organized, distributed and legitimated a knowledge management discourse limited in its conceptual framework. Establish conceptual 


\section{Al Macrothink}

Case Studies in Business and Management

ISSN 2333-3324

2018, Vol. 5, No. 1

basis of analysis to explain the significance to knowledge management discourse, as an integrator of regulative discourse and instructional discourse and its impact in shaping the knowledge management models in public accounting programs, which as mediating structures and symbolic message as forms of meaning, inherently reproduce relations of power and principles of specific control. The structure symbolic accounts should be studied dynamically depending on the environment, time and space.

The organizations' need of employing new and powerful techniques in strategy formulation led to investigate corporate organizational knowledge management policy status in industrial organizations, as well as whether to give priority to internal or external environments to obtain a stronger model for implementation of industrial organizations. The role of knowledge management is to implement knowledge management strategy. Effective organizational knowledge management policy is one of the important factors in comfort organizations success as Figure 1.

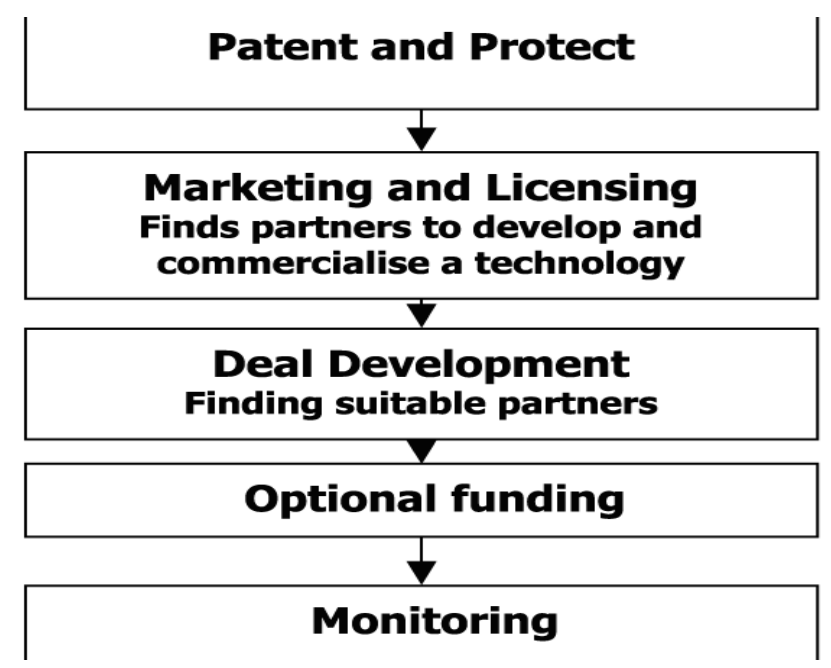

Figure 1. Knowledge management policy strategy

This strategy type emphasizes high corporate organizational knowledge management policy, as a result, suggests organizations to encourage knowledge management policy, and constantly look for new products and markets, that is, to prioritize external environment to attract new markets with novel attributes. Knowledge management policy strategy aims at exploiting the synergy resulted from several organizations' integration for offering some distinct products cooperatively.

The algebraic sum of outcome obtained from this cooperation is more than the total outcome of those organizations' activities individually. One way to promote comfort organizations development is to offer organizational knowledge management program in organization that meets the market demands of the productive sectors.

Accounting organizational knowledge management programs have suffered from a 
conceptual framework that allows, on strong references, obtaining in the analysis of the different interactions and regulatory mechanisms underlying control, to the discourses, practices, agents and contexts involved in the configuration of knowledge management discourse and curriculum models.

Benevolent superintendence act individually or collectively through professional organizations that allow a special kind of association with different characteristics in relation to commercial comfort organizations. The requirement of compliance with professional standards extends the collective exercise of the profession are subject to sanctions by professional organizations.

With these elements must be based knowledge management and professional experience and minimum limits must have a professional to be accepted as professional accountant.

Benevolent superintendence generate the general policies, international auditing standards, ethical guidelines, guidelines and organizational knowledge management and other aspects that are related to the task professional. Moreover, this knowledge management policy reduces competition, hereupon; the amount of competitive renovation decreases. Organizations with low organizational knowledge management policy have to find ways to create variation in their products.

Further, environmental shifts are so much that the organization has to focus on the external environment primarily. As a result, it decides to cooperate with level organizations to use the obtained shared synergy for overcoming its rivals.

Benevolent of the activity scope allows the resources to be concentrated, and obtains a competitive superiority to the rivals. The purpose of focusing on particular products and services is to satisfy the needs of small groups of consumers. Effective factors in organizational knowledge management strategy include high variety in products, unlimited and indistinct market, unlimited geographical area, unlimited activity, research, and development concentrated on production.

In the case of knowledge management policy strategy, products' success, adding more geographical areas or entering other knowledge management policy segments such as other layers of consumer in the same knowledge management policy, etc. can raise selling rate. An organization pursuing this strategy, attempts to offer its services and products to new geographical areas. Focusing completely on external environment, the organizations are likely to be able to find new knowledge management policies for their products. These organizations are regarded as opportunists, which can make double success by using knowledge management policy development strategy.

Quality of life, social unity and international responsibility are subject matters of further so-called social indicators of sustainability. These indicators are introduced, their integration into the benevolent superintendence system is discussed and the entrepreneurial use demonstrated.

The benevolent superintendence concept of the knowledge management development 
includes superintendence rules, their actors and scopes of action, indicators and objectives as well as a monitoring of the achieved progress and the consequential further adaptation to changing priorities.

The present knowledge management superintendence systems, like as the quality superintendence according, the environmental superintendence or already integrated systems will align themselves with the development in medium term and nurture it. Important actors in organizational knowledge management policy process are the comfort organizations.

Therefore, benevolent superintendence systems have to guarantee a sustained and future-oriented development of the comfort organizations. It is demonstrated how a sustainability benevolent superintendence can be incorporated into the operational practice by means of proven systems, like quality and environmental superintendence, by integrating sustainability performances. Indicators of knowledge management, like preservation of resources, reduction of the surface consumption and renewable usage of energy but also economic precaution, education and innovation guarantee a high eco-efficiency of operational processes.

\section{Benevolent Superintendence}

Benevolent superintendence combining prioritization of internal and external environments with organizational knowledge management policy status in one matrix possessed strategic options, from which organizations can choose a proposed strategy according to their organizational knowledge management policy intensity and prioritization. Selection of a strategy with respect to a organization's situation, in addition to enabling the organization to develop, and effectively accomplish its goals, could indicate the direction towards higher situations in the matrix.

There is benevolent superintendence who argues that formal written planning may be inappropriate for the comfort organizations but this seems a minority view. It can be argued that organizational knowledge management policy is as important to comfort organizations as to larger organizations and standard textbooks on entrepreneurship offer chapters on knowledge management plan whilst a range of specialist publications outline the best ways of writing organizational knowledge management planning (Sahlman, 1997, p. 67; Monks, 2001, p. 41; Naffziger et al., 1991, p. 21).

A fundamental proposition in knowledge management strategy is that organizational knowledge management planning must be aligned with customers and competitive advantage.

Unfortunately, organizational knowledge management planning performance measurement literature has provided ambiguous guidance to knowledge management managers.

In comfort organizations, where an organizational knowledge management planning exists, the preparation of the organizational knowledge management policy may have been driven by external forces. The most obvious of these are the requirements of external agencies providing funding for either start up or expansion. However, the organizational knowledge 
management planning may serve as a strategic planning document for the managers, entrepreneurs and educated workers, a plan to guide the knowledge management and serve as a basis for taking strategic decisions and also it may serve as a subsequent monitoring device (Deakins, 2003, p. 329; Fegh-hi farahmand, 2005, p. 118).

In view of its perceived ongoing value to the small business it might be expected that organizational knowledge management policy would be a feature of many, if not most, comfort organizations.

In order to achieve knowledge management success, it is important to understand the relationship between organizational knowledge management policy by benevolent superintendence and strategy deployment success. As superintendence itself becomes more emphatically fast-paced and intuitive, in order to deal with complexity and unpredictability, research is beginning to accumulate showing that coaching formats used in superintendence support are more effective than training in the older logical comprehensive pursuits.

The organizational knowledge management policies relative to various situations were:

- Innovativeness of benevolent superintendence by heterogeneous diversification,

- Product development by cooperation or focus,

- Vertical integration or cost and horizontal diversification for knowledge management policy development,

- Horizontal integration for stability.

Among the strategies, innovativeness was related to the ideal situation and stability referred to the poor condition of an organization. The nature of the benevolent superintendence is seen as critical in other aspects (Nayak et al., 1994, p. 425; Fisher, 2002, p. 89) of the activities of comfort organizations. A selection of the benevolent superintendence characteristics is the potential to influence an owner manager's propensity to undertake organizational knowledge management policy.

Predictions of the direction in which the variables (Fegh-hi Farahmand, 2002, p. 345; Smith, 1967 , p. 145) will operate are inevitably problematic as there is little prior work on the determinants of organizational knowledge management policy upon which we can draw (Smith, 1967, p. 25; Curran et al., 1994; Fegh-hi farahmand, 2005, p. 37; Kuratko et al., 2004, p. 64):

1) Benevolent superintendence ability: This variable has been identified as important in a number of studies.

2) Benevolent superintendence experience: It may be strongly linked to ability and it could be argued that it might work in two ways. A long number of years running an organization as a benevolent superintendence might increase a propensity to plan future directions for the knowledge management or indeed, once the initial phases had passed and funding secured planning might well be less of a priority. 
3) Benevolent superintendence education level: In the context of organizational knowledge management policy, this variable might seem reasonable to hypothesis that the more highly educated benevolent superintendence will tend to be more aware of the desirability of organizational knowledge management policy and thus, organization run by the better educated benevolent superintendence might be more likely to have knowledge management plans.

4) Benevolent superintendence knowledge management: A distinction here may be drawn between those for whom the current organization is their first and serial founders (Bridge et al., 1998)

5) Benevolent superintendence educated workers: This was identified as an influence on organization behavior and in the context of organizational knowledge management policy, benevolent superintendence with previous work experience in larger organization, perhaps where organizational knowledge management policy was seen as an important part of knowledge management behavior, would tend to encourage organizational knowledge management policy in organization.

6) Benevolent superintendence organizing: Organization founders are drawn either from operatives or from those with previous managerial experience.

7) Benevolent superintendence strategy: Here it might be argued that benevolent superintendence moving into a new sector might be encouraged to plan rather more than those whose businesses were in sectors in which they had considerable prior experience.

8) Benevolent superintendence potential: This was introduced into the analysis as it might be expected that local benevolent superintendence, which grew up in the geographical area under study, will tend to be introspective and less receptive to contemporary superintendence practice.

\section{Organizational Knowledge Management}

The relationships between comfort organizations and their localities have become an important research area and organization with links with local knowledge management institutions might be more likely to knowledge management plan. The argument here would be that mixing with local knowledge management leaders would increase awareness of the value of organizational knowledge management policy.

Further, the characteristics which have been measured can be grouped into environmental and organizational knowledge management planning variables rather than those variables which measure attributes of the personality of the benevolent superintendence.

It is also recognized that the relationships only significant at a relatively low level but this reflects, in part, the small size of our initial sample. Therefore useful conclusions can be drawn as follows:

1) Organizational knowledge management policy is a characteristic of the comfort organizations that there still remains a high proportion of benevolent superintendence of 
comfort organizations who does not undertake organizational knowledge management policy. Benevolent superintendence characteristics and organizational knowledge management planning variables can be an influence upon whether or not small comfort organizations undertake organizational knowledge management policy when controls have been introduced for sector and size.

2) The key benevolent superintendence characteristics, associated with a greater tendency to undertake organizational knowledge management policy, are a higher level of education level, experience and running knowledge management.

3) There was no evidence that previous superintendence experience was linked to a higher propensity to knowledge management plan. That benevolent superintendence with superintendence experience is somewhat cynical of the value of paper exercises and the writing of knowledge management plans.

4) Although this is a study of comfort organizations in one zone, this paper has demonstrated that benevolent superintendence characteristics cannot be ignored in trying to understand the extent to which comfort organizations display a commitment to organizational knowledge management policy.

5) Success is most likely to come from policies to that benevolent superintendence with the characteristics of planners but who are not yet planners. These are the benevolent superintendence that may be unaware of the benefits of organizational knowledge management policy rather than outwardly hostile. However, benevolent superintendence characteristics are rarely in the public domain so such targeting becomes difficult.

6) Analysis of the strategic characteristics of benevolent superintendence identified a set of variables.

7) Gaining the sustained co-operation of fellow team members requires emotional leadership. Where such leadership is available, much forgiveness is afforded. Performance knowledge management in a manager links to conceptual knowledge management because the corporation's key competence, its knowledge management and industrial concept knowledge management capability index, is the key to success in a knowledge driven economy.

8) Where creative responses of many kinds are required, managers will prove to be at the heart of superintendence excellence, which empower their colleagues and clients to expand their comfort organizations performance and utilize a higher proportion of the comfort organizations potential.

\section{Organizational Knowledge Management Planning}

Comfort organizations to primarily determine their entrepreneurial situation on three levels of low, medium, and high, and then select their prioritization in environmental investigation from the options of focusing on inside the organization, focusing on both inside and outside the organization, and focusing on outside the organization.

Benevolent superintendence recent research reviewing corporate coaching programs that we 
can see this move from intuition towards rationalized models as complementary and off-setting to developments in strategic superintendence (Mintzberg, 1994, p. 89; Mintzberg, et al., 1998, p. 45; Schwenk et al., 1993, p. 17). Like all scientific enterprises, a period of accumulation of evidence will be required before definitive conclusions may be drawn (Brown et al., 1998, p. 88; Deakin et al., 2003, p. 64; Mason et al., 2004, p. 3). However, there are early gleanings that evidence based evaluation research is underway.

Central to success as knowledge creators is the culturing of independent individuals, organizational members able to re-invent businesses as required. Such capabilities are not nurtured in high compliance systems that penalize out-of-envelope contributions (Goleman, 1996, p. 89; Goleman et al., 2002, p. 185; Hamel, 2001, p. 89; Fegh-hi farahmand, 2003, p. 67).

To assist in understanding the process used in a certain application; avoid potential misconceptions regarding the intent and define the activities associated with specific value studies, reclamation has defined four distinct types of organizational knowledge management policyes. Also the organizational knowledge management policy is a tool to identify key activities that create value and costs in knowledge management.

Therefore organizational capability relies in particular on coaching superintendence skills, which rely on emotional intelligence and emphasis one-to-one, dialoguing, subordinate empowerment and mutually agreed targeting. In relation of organizational knowledge management policy competencies including outsource less critical resources if better organizational knowledge management or cost and own competencies core business, three characteristics are competitive advantage and difficult to imitate.

Anyhow tactical actions steps for coupling organizational knowledge management with customers or service receivers including to knowledge management, segment, proposition, and network recovering satisfaction are as follows (Curran et al., 1994; Fegh-hi farahmand, 2004, p. 358; Fegh-hi farahmand, 2005, p. 187; Nayak et al., 1994, p. 47; North et al., 1997, p. 187):

1) Benevolent superintendence support: An organization's total key performance factor efforts must begin at the very top and begin with the board of directors.

2) Benevolent superintendence plan: An action plan based on the survey feedback should then be formulated by the top superintendence and communicated at every board meeting.

3) Benevolent superintendence vision: Develop a vision the organization does not have one already. The key to the initial adoption of key performance factor is continuous communication of the vision within a comprehensive communication plan.

4) Benevolent superintendence improvements: Senior managers need coaching as the new theorists in coaching argue; coaching empowers individuals to achieve their inherent potential.

5) Benevolent superintendence responsibility: The responsibilities accept of a senior key performance factor committee can include: establishing strategic key performance factor 
goals, allocating resources, sanctioning key performance factor improvement teams, reviewing key indicators of quality, estimating the cost of poor rescuer, ensuring adequate training of employees and recognizing and rewarding individual and team efforts.

These definitions allow reviewers of a study to key performance factor understand its scope and limits. To ensure the opportunity to achieve the highest value, value program staff attempt to keep superintendence or administration directed mission charges flexible enough to allow knowledge management. This staff make most of the recommendations for administrative and procurement processes that could benefit from studies (Fegh-hi farahmand, 2009, p. 97; Steele, 1997, pp. 28-68). Anyhow is the need to develop a means to inform key performance factor of the available resources and how to obtain assistance. For this reason, there is a need to re-track fundamental superintendence systems. Such concepts as investment valuation, ethical trading, stakeholder consultation, corporate social responsibility, value investment, preoccupy institutional investor communities. In any case, the level of uncertainty is continuing to increase even as consumer prosperity overlaps into the new century, reacting against the undoubted brilliance of the recent industrial era.

However, the mainly qualitative evidence available to date suggests that organizational knowledge management planning within comfort organizations is an activity of a minority (Fegh-hi farahmand, 2002, p. 254). There may be a number of reasons for the lack of organizational knowledge management planning. Historically the typical benevolent superintendence has tended not to have pursued higher levels of education level or to take formal knowledge management training.

Hence there are two possible reasons why benevolent superintendence tends not to plan that they are emotionally unsuited to it. They think and act intuitively and they are simply unaware of the various tools which would enable them to plan systematically. A further constraint, likely to restrict organizational knowledge management planning by benevolent superintendence, is that they may not have sufficient knowledge management information to prepare a formal plan.

A lack of formal organizational knowledge management planning among comfort organizations does not necessarily mean that organization is badly managed. It does, however, suggest that benevolent superintendence miss out on the opportunity to consider the overall direction of the knowledge management and superintendence decisions may be made on the basis of poor information (Curran et al., 1994, p. 39; Fegh-hi farahmand, 2009). The characteristics of the organization and benevolent superintendence and also comfort organizations strategies hereafter termed knowledge management strategy, influencing benevolent superintendence behavior which might be used to inform analysis of the determinants of organizational knowledge management planning in comfort organizations. Organization characteristics were controlled out of analysis in order to focus our attention on the benevolent superintendence and organizational knowledge management planning variables. 


\section{Knowledge Management Organizations}

With the development of the organizational knowledge management policy, the challenges faced by benevolent superintendence are larger and larger and the former method. The benevolent superintendence should comfort win more customers' favor and obtain more profit resources by the knowledge management thinking and measures. Through clearing up the correlations between organizational knowledge management and creating a sustainable competitive advantage, this study has shown the synergistic between both sides and discusses how organizational knowledge management, key performance factor and benevolent superintendence can lead to a sustainable competitive advantage.

benevolent superintendence in designing and delivering organizational knowledge management policy, does not only mean high knowledge management, but it extends to encompass creativity in the way organizational knowledge management policy are delivered through using latest and effective techniques and applications. Frontline employees' skills and abilities may be developed by providing them with the required materials as well as supportive techniques, thus, leading to more knowledge management strategies in delivering knowledge management.

Comfort organizations may also present the required facilities to achieve zero-error transactions regarding personal, real estates, or purchasing mortgages, either on the long or short run based on key performance factor. It is also important that benevolent manager strategic vision and perception of knowledge management policy to be in line with creating a sustainable competitive advantage on the long run. Creating an organizational climate encourages, assimilates and promotes knowledge management, through facilitating team works, offering moral and material incentives and purifying the relationships between all parties in the comfort organizations in question are all central to generate knowledge management.

Organizational knowledge management planning does not only depend on acquiring new knowledge, but also on leveraging existing knowledge through knowledge sharing and application within the organization. However, benevolent managers should be noted that some managers commented on the concept of knowledge management by stating that although they are convinced that knowledge management in comfort organizations is essential, they face some difficulties in its application.

Some difficulties stems from the gap of understanding and communications between managers at higher and lower level. Other difficulties stems from the weak understanding of how to transfer customer needs into technical specifications. Other stated that the concept of knowledge management in its broad definition is understandable; however, when it comes to details, managers face some difficulties on how to reap the ultimate rent out of that knowledge management.

The sustainable competitive advantage stems from the organization ability on retaining and expanding its strategic base through using customer's insight to drive new and novel ideas and dedicate organizational structures and funds to generate knowledge management. It is not 
enough for knowledge management institutions to have pocket of successful knowledge management, benevolent managers also have to ensure that the efforts are developed and sustained throughout the organization.

Organizational knowledge management policy performance and resources allocation should be viewed in favor of long term execution. Knowledge management organizations should also promote for knowledge management through presenting some organizational mechanisms that assists in generating new ideas. Knowledge management organizations may also promote knowledge management through establishing clear knowledge management incentives, setting clear targets and metrics for developing and sustaining knowledge management and systematically providing ways for knowledge management ideas. Benevolent superintendence is a subgroup of customers sharing one or more characteristics that cause them to have similar product needs. Such a classification process is organizational knowledge management segmentation and marketers may develop a specific marketing strategy for each segment. Providing examples of a particular theme to a learner either human or computer, a conclusion that is as consistent as possible with the training data will be drawn.

\section{Knowledge Management Organizations Important}

Knowledge management organizations should have both formal and informal knowledge management structures and based on that, they should be able to identify barriers that hinder them from commercializing knowledge management. To compete successfully in an organizational knowledge management, a comfort organization has to know sufficient about the wants and needs of customers but they have different preferences for products and services. It is necessary to classify customers into different segments based on various customer requirements. An inductive organizational knowledge management policy to market segmentation will be described. In terms of comfort organizations as a component of the marketing mix, previous research has shown that most organizations have ignored that crucial role of innovative marketing strategies as a tool to create sustainable competitive advantage.

This study informs the knowledge management manager that knowledge management strategy should be the primary determinant of an organization's organizational knowledge management policy and benevolent superintendence framework. It guides the manager in a way that avoids the organizational knowledge management policy and benevolent superintendence which results in sub-optimization of the performance measurement portfolio.

The positive training set contains example data that are relevant to a knowledge management theme i.e., relationships between customer attributes and responses to marketing events while the negative training set contains example data that are irrelevant to the same knowledge management theme.

These different training sets can provide an efficient knowledge management environment for achieving a more accurate knowledge management result than only one training set in the traditional inductive knowledge management method can do. An experiment with real data of customers was performed. 


\section{Mll Macrothink}

Case Studies in Business and Management

ISSN 2333-3324

2018, Vol. 5, No. 1

The results show that the inductive knowledge management policy and the knowledge management feedback technique are effective and able to attain high performance of market segmentation. The objective of this study was to evaluate the impact of benevolent superintendence in the organizational knowledge management planning on creating a sustainable competitive advantage. Comfort organizations that undertook more knowledge management activity, that were more consistent in that activity and whose composition of activity was somewhat differentiated from the industry norm tended to have a sustainable comfort organizations advantage and display superior performance. Knowledge management activities are undertaken by comfort organizations and which were found to have sustainable competitive advantages. When comfort organizations become more involve with knowledge interaction with their customers during services encounter and service delivery, they will be more able to understand customer needs and that in return will make organization more innovative.

Organizational knowledge management in comfort organizations reflects the organization ability to create and expand knowledge through social interaction between both explicit and tacit knowledge, which in this case refers to the knowledge interaction within the organization itself and its clients. Benevolent superintendence represents the organization ability to transfer this knowledge into socioeconomic solutions and explains that in order for marketing information to be innovative, organizations are required to have core competences regarding; operating and production capabilities, design, engineering and associated superintendence capabilities and research and development capabilities. Empirical research has shown that organizational knowledge management policy does not only depend on acquiring new knowledge, but also on leveraging existing knowledge through knowledge sharing and application within the organization.

The involvement of consumers to support the process of marketing innovations is debatable. The consumers may not be able to specify exactly what they want in the process of developing future products. The consumers lack foresight, since, it is difficult for them to imagine and present ideas regarding something that does not exist and may only make suggestions to improve existing products.

\section{Conclusions and Discussion}

The literature argues shows that the extent to which each determinant of performance impacts firm performance is a function of the performance metrics. Further, define performance as the sum of all processes that will lead managers to taking appropriate actions in the present that will create a performing organization in the future or in other words, doing today what will lead to measured value outcomes tomorrow.

Creative knowledge management building is found in knowledge-based industries, which span many sectors finance, technology, media and learning.

Empirical research concluded that the involvement of consumers by need inputs, concept reviews and product tests contributes to the superiority of a product and raise the potential of having a sustainable competitive advantage on the long run. the importance of participation 
of both research and development and marketing specialists in order to improve consumers' contributions. Such participation and interaction across multiple resources and departments can provide the opportunity for the organization in question to be a market leader in its field. Continuing involvement of consumers with developers in an integrated fashion sustains the melding of consumer needs with technical capabilities.

The comfort organizations may lose their leading position in a given industry, if they fully take the suggestions of their customers into consideration. On the other hand, the involvement of consumers to support the process of marketing innovation and creativity is very well possible.

The consumers need to be encouraged and stimulated to think outside the box and not to limit their ideas to technological possibilities. For knowledge management managers, the organizational knowledge management policy performance measurement is an area that represents a significant opportunity for business investment and superintendence attention. The interdisciplinary conceptual model will provide guidance to knowledge management managers in developing contextually relevant organizational knowledge management policy measures. This study provides knowledge management managers with specific benefits such as:

1) A strategically aligned framework for clearer logic behind actions. More appropriate organizational knowledge management policy + benevolent superintendence should result in less internal conflict.

2) A framework that will provide organizational knowledge management policy + benevolent superintendence guidance. In other words, improving one performance measure can adversely affect other performance measures where a comprehensive framework is not used.

The optimization of organizational knowledge management processes is the most promising strategy when increasing volumes is hard to realize in a saturated market. The knowledge management increase of would translate into double profit growth for many organizations particularly for organizations competing in a saturated market. Previous literature has also shown that organizational knowledge management promotion can generate positive cumulative effect on brand choice and purchase quantity and on category incidence. This in return, might lead to having a sustainable competitive advantage on the long run.

Furthermore, comfort organizations spend billions of dollars annually on various forms of advertising to influence current and potential customers to buy their products and services. Moreover, concluded that organizational knowledge management in the comfort organizations may enhance cash flows, accelerate cash flows, reduce vulnerability in cash flows and increase the residual value of the organization.

The organizational knowledge management plays an comfort role in understanding the environment by collecting, disseminating, analyzing and storing information. It includes both a set of functional activities as production, promotion, pricing and distribution and a mind-set that emphasizes the creation of value to alter customer behavior in certain ways. Furthermore, product development process as an important and essential part of innovation. The relative 
advantages of new products are crucial determinant of accelerated consumer adoption rate and new product success. In the organizational knowledge management policy, the continuous innovation helps banks to develop new and differentiated offerings in highly homogenized comfort organizations.

A number of customer profiles and their customers' responses to marketing events are used as training data based on which the ways to classify customers into different segments are learnt. A common drawback of inductive knowledge management is that the training examples may be an incomplete representation of the subject to be learnt and they will lead to an inappropriate conclusion. Organizational knowledge management feedback technique overcome this problem by using two training sets as positive and negative to correct the wrong conclusion as much as possible.

It is crucial for comfort organizations to carefully evaluate both their internal capabilities and the external environment, when deciding where to focus their channel innovation efforts. It might be more convenient for some comfort organizations to focus their knowledge management efforts within the branch channel, while for other comfort organizations it may be more convenient.

\section{References}

Bridge, S., O’Neill, K., \& Cromie, S. (1998). Understanding Enterprise, Entrepreneurship \& small Business (p. 124). London: Macmillan Business. https://doi.org/10.1007/978-1-349-26171-0

Brown, S., \& Eisenhardt, K. (1998). Competing on the Edge (p. 70). Boston: Harvard Business School Press.

Curran, J., \& Blackburn, R. (1994). Business planning and Local Economic Networks (pp. 31-49). London: Paul Chapman.

Deakin, D., \& Freel, M. (2003). Entrepreneurship and Business planning (pp. 302-412). London: McGraw Hill.

Fegh-hi Farahmand, N. (2001). Administration Management Process (1st ed.). Islamic Azad University, Tabriz branch, Iran.

Fegh-hi Farahmand, N. (2001). Management in Iran (2nd ed.). Governmental Management Training Publication of Tabriz, Iran

Fegh-hi Farahmand, N. (2003). Management of Strategic Structure of Organization (4th ed.). Islamic Azad University, Tabriz Branch, Iran.

Fegh-hi Farahmand, N. (2003). Permanent Management of Organization (1st ed.). Tabriz, Iran: Frouzesh Publication.

Fegh-hi Farahmand, N. (2009). Organizational Strategic Plan compilation (1st ed.). Tabriz, Iran: Frouzesh Publication.

Fegh-hi Farahmand, N. (2011). Technology Management of Organization (2nd ed.). Tabriz, 
Iran: Frouzesh Publication.

Fegh-hi Farahmand, N. (2014). Strategic Management of Organization (2nd ed.). Tabriz, Iran: Frouzesh Publication.

Fegh-hi Farahmand, N. (2015). Active and Dynamic Management of Organization (3rd ed.). Tabriz, Iran: Frouzesh Publication.

Fegh-hi Farahmand, N. (2011). Managers Specialized Dictionary (1st ed.). Tabriz, Iran: Frouzesh Publication.

Fegh-hi Farahmand, N. (2018). Management of Organization Techniques (1st ed.). will come at the future.

Fegh-hi Farahmand, N. (2016). Advanced Strategic Management (1st ed.). Islamic Azad University, Tabriz branch, Iran.

Fegh-hi Farahmand, N., \& Dabaghi Sadr, M. (2015). Management of infrastructural development for leather industry. Tehran, Iran: Sokhanvaran Publication.

Fegh-hi Farahmand, N. (2016). Imperative Strategic Planning as Improvement of the Decision Making of Organization. International Journal of Innovative Studies in Sciences and Engineering Technology (IJISSET), 2(7), 27-37.

Fegh-hi Farahmand, N. (2016). Keeping Quality Employees with a Quality Strategy Improvement by Key Decision Making Managers. International Journal of Advanced Scientific Research \& Development (IJASRD), 3(2), Version I, 21-39.

Fegh-hi Farahmand, N. (2016). Organizational Center of Decision Making as Consideration and Initiating Structure Approach. International Journal of Advanced Scientific Research \& Development (IJASRD), 3(4), 44-64.

Fegh-hi Farahmand, N. (2017). Decentralization of Authority in Organizational Management in Decentralized Decision Making Organizations. International Journal of Advanced Information Science and Technology (IJAIST), 6(1), 33-42.

Fegh-hi Farahmand, N. (2017). Focus on Human Resource as Improvement of the Flexible Manufacturing Operation of Organization. International Journal of Trend in Scientific Research and Development (IJTSRD), 4(1), 470-480.

Fegh-hi Farahmand, N. (2017). Organizational Joint Consultative Machinery as Job instruction and Communication Strategic Approach. International Journal of Business Marketing and Management (IJBMM), 2(1), 11-20.

Fegh-hi Farahmand, N. (2017). Organizational labor augmenting technical changes coefficient as labor productivity qualifications. International Journal of Advanced Scientific Research \& Development (IJASRD), $\quad 4(7), \quad 1-18$. https://doi.org/10.26836/ijasrd/2017/v4/i7/4703

Fegh-hi Farahmand, N. (2017). Organizational Lateral and Diagonal Communication Policy 
as Linguistic Cooperation. International Journal of Advanced Scientific Research \& Development (IJASRD), 4(2), 43-57.

Fisher, A. (2002). Annie weighs in on executive coaching and untruths on resumes. Fortune Magazine, 13 May, o 89.

Goleman, D. (1996). Emotional Intelligence (p. 58). London: Bloomsbury.

Goleman, D., Boyatzis, R., \& McKee, A. (2002). The New Leaders (p. 178). London: Little, Brown.

Hamel, G. (2001). Leading the Revolution (p. 89). Boston: Harvard Business School Press. https://doi.org/10.1016/S0737-6782(01)00097-2

Kuratko, D. F., \& Hodgetts, R. M. (2004). Entrepreneurship: Theory, Practice (p. 64). Mason, Ohio, Thomson South Western.

Mason, C., \& Stark, M. (2004). What do investors look for Business Plan. International small Business Journal, 22, 3.

Mintzberg, H. (1994). The rise and fall of Strategic Planning (pp. 81-109). Upper Saddle River, New Jersey: Prentice Hall International.

Mintzberg, H., Alstrand, B., \& Lample, J. (1998). Strategy Safari (pp. 23-67). The Free Press.

Monks, R. (2001). The New Global Investor (pp. 24-49). London: Capstone.

Naffziger, D., \& Kuratko, D. (1991). An Investigation into the Planning In small Business. Journal of Business and Entrepreneurship, Fall, p. 21.

Nayak, A., \& Greenfield, S. (1994). The Use of Superintendence Accounting Information. Finance and the organization (p. 47). London: Rutledge.

North, J., Blackburn, R., \& Curran, J. (1997). Reaching small Business and Enterprising Futures. London: Paul Chapman.

Sahlman, W. A. (1997). How to write a great Business Plan (pp. 61-98). Harvard Business Review.

Schwenk, C. R., \& Shrader, C. B. (1993). Effects of Formal Strategic Planning, Entrepreneurship: Theory and Practice (p. 17).

Smith, N. R. (1967). The Entrepreneur and His Organization, University of Michigan: Bureau of Business and Economic Research (pp. 112-184).

Steele, R. S. (1977). Power motivation, activation and inspirational speeches. Journal of Personality, 45, 28-68. https://doi.org/10.1111/j.1467-6494.1977.tb00592.x 


\section{Copyright Disclaimer}

2018, Vol. 5, No. 1

Copyright for this article is retained by the author(s), with first publication rights granted to the journal.

This is an open-access article distributed under the terms and conditions of the Creative Commons Attribution license (http://creativecommons.org/licenses/by/4.0/). 